\title{
IDENTIFICATION OF AGRONOMIC MANAGEMENT UNITS BASED ON PHYSICAL ATTRIBUTES OF SOIL
}

\author{
J.L. Cucunubá-Melo ${ }^{1}$, J.G. Álvarez-Herrera ${ }^{2 *}$ and J.H. Camacho-Tamayo ${ }^{3}$
}

${ }^{1}$ Coordinador planta de compostaje, PALMACEITE S.A., Aracataca Magdalena, Colombia.

${ }^{2}$ Grupo de Investigaciones Agrícolas (GIA), Facultad de Ciencias Agropecuarias. Universidad Pedagógica y Tecnológica de Colombia, Tunja. Av. Central del Norte. ${ }^{3}$ Programa de Ingeniería Agrícola, Facultad de Ingeniería, Universidad Nacional de Colombia, Bogotá.

*Corresponding author: jgalvarezh@gmail.com

\begin{abstract}
Oil palm (Elaeis guineensis Jacq) is an alternative for the development of productive systems in the tropics. By determining the spatial variability of physical characteristics of soil, specific recommendations for certain areas within a zone can be made. Geostatistical analysis can determine the existence and characteristics of the spatial distribution and is an appropriate tool for analyzing the spatial variability of soil properties. The aim of this study was to determine areas with homogeneous physical characteristics in order to establish agricultural management units, using geostatistical techniques. For this study, 62 samples were collected in 10.6 ha in the municipality of El Retén (Magdalena, Colombia). The properties analyzed were: content of sand, silt and clay, particle density, bulk density, total porosity, gravimetric and volumetric water content, hydraulic conductivity and infiltration rate. All properties showed spatial correlation, with adjustments to semivariograms theoretical models, mostly to the spherical model, with ranges between 84.87 and $218.60 \mathrm{~m}$ and moderate to strong spatial dependence. The contour maps obtained through ordinary kriging, allowed for the identification of the relationship between the different physical properties of the soil and subsequent classification to determine the Agronomic Management Units (AMU).
\end{abstract}

Keywords: geoestatistics, semivariogram, kriging, precision farming, Elaeis guineensis Jacq.

\section{INTRODUCTION}

In Colombia, planting of oil palm (Elaeis guineensis Jacq) is often carried out in soil with low fertility and in areas with other constraints, in which crop yield is affected by high fertilizer costs, land improvement and counteractions to biophysical problems (Rubiano, 2005). A high proportion of the current crop of oil palm growing on soils that were previously used in rice farming or livestock farming generates changes in soil properties over time, such as increased bulk density, reduced hydraulic conductivity and deterioration of soil structure (Munévar, 1998). In addition, many of the cultivated soils of oil palm in the north of Colombia have special characteristics, like high montmorillonite clay content and vermiculite-illite integrated 2:2 and 2:1. In these soils, it is 
typical to find physical constraints such as compaction, high bulk density values and low hydraulic conductivity (Garzón, 2008).

In a study conducted in Central America, Durán and Ortíz (1995) concluded that soil aeration and water deficiency affect the production of palm oil. These authors found that production is linked to soil type, and identified different zones according to the physical properties, for instance sandy loam textured soils showed higher productivity, due to adequate aeration, a condition that may be affected temporarily by the presence and frequency of high precipitations. On the other hand, it appears that the management provided in most palm oil plantations is homogeneous, without considering the spatial changes occurring in different soil properties, variability due to various natural processes (climate, topographic interaction with plant and animal species) or human activities and, in particular, to the different cultural practices carried out in agricultural production (Molin et al., 2008). Spatial variability, defined as patterns in the spatial distribution and relationships between soil properties and crop productivity, has been studied in different soil types, and several areas have been identified for carrying out management tasks such as fertilization, soil preparation, irrigation and drainage design, among others (Fietz et al., 1999, Camacho-Tamayo et al., 2008, RamírezLópez et al., 2008).

Currently, there is a global trend in the agricultural sector to generate information about causes of spatial variability of soil properties, in order to facilitate decision making with different tools of geographic information, that allow the management of crops through techniques known as agricultural management units (AMU), or precision agriculture and site specific management. These techniques have enabled the development of models and management systems more suitable for agriculture (Godwin and Miller, 2003). A geographic information system is a set of tools for capturing, storing, retrieving, processing, displaying and analyzing various types of geographically referenced data. This information seeks, among other things, to generate information that can be translated into thematic maps that can be combined to analyze possible interactions between variables (Burrough and MacDonnell, 1998). Such a tool is geostatistical analysis, which is used to identify the spatial distribution and behavior of the traits studied by setting theoretical semivariogram models that show the correlation of the variable in different directions and distances of separation. These models can estimate the values of the studied variable in areas not sampled by interpolation through ordinary kriging (Dale et al., 2002).

Therefore, the objective of this study was to determine the spatial variability of physical properties of soil through geostatistics and kriging techniques for the identification of agricultural management units (AMU) in an area planted with oil palm.

\section{MATERIALS AND METHODS}

\section{Study site and field experiment conditions}

The study was carried out in a commercial oil palm plantation in El Libano, located in the municipality of El Retén (Magdalena), with the geographic coordinates $10^{\circ} 38^{\prime} \mathrm{N}, 74^{\circ} 19^{\prime} \mathrm{W}$ and $15 \mathrm{~m}$ a.s.l. The area has a warm climate with average temperature of $28^{\circ} \mathrm{C}$, relative humidity of $70 \%$ and an average annual 
rainfall of $850 \mathrm{~mm}$ that is concentrated in the months from May to November. Gently undulating terrain was found in this zone with inclines between $2 \%$ and $5 \%$. The soil characteristics were determined, following the methodology proposed by the USDA (2006), as: the soil is Typic Duraquert, deep, with angular and subangular blocky structures, the texture of A and B horizons is clay loam, a $\mathrm{pH}$ ranging from neutral to basic (6.8 to 7.9) and little presence of macropores $(<4 \%)$.

The study area has 10.6 ha planted with 2 year-old oil palm, variety Deli X Nigeria. This area was traditionally planted with rice and before the cultivation of oil palm it was a place for animal husbandry for close to 10 years, and had flooding problems until 2006 when it was drained and leveled with the construction of channels in order to establish a palm plantation. Due to the excessive mechanization and overgrazing the zone was subjected to, it had compaction problems. Currently, kudzu (Pueraria phaseoloides) is used as ground cover for strategy management and soil conservation.

\section{Field study}

Initially, an altimetry study, with the help of a level and geo-positioning system (GPS), was employed to establish a map of the area and identify areas with potential drainage problems and flooding. For sampling, a grid of 62 points was established, regularly spaced every $45 \mathrm{~m}$, in mutually perpendicular directions. At each point, an undisturbed soil sample was collected in cylinders with a diameter of $5 \mathrm{~cm}$ and height of 2.5 $\mathrm{cm}$, at a depth between 0 and $30 \mathrm{~cm}$. With these samples, the following parameters were determined: the contents of sand, silt and clay by the Bouyoucos Hydrometer method, bulk density (Da) by the mass volume method, particle density $\left(D_{r}\right)$ by the pycnometer method, total porosity (Pt) and gravimetric moisture content (HG) and volumetric moisture content (HV). At each sampling point, infiltration was also tested with a double ring infiltrometer as well as saturated hydraulic conductivity by Auger Hole method (Montenegro and Malagon, 1990).

\section{Statistical analysis}

Descriptive statistics were initially used for analyzing the data, for calculating the mean, median, minimum and maximum coefficient of variation (CV), skewness and kurtosis, and the KolmogorovSmirnov test for normality, which were estimated using SPS 16.0 software. Thus, normality was verified for the attributes which were not indispensable, and provided better predictions when it was combined with geostatistical techniques (Diggle and Ribeiro, 2000). For CV analysis, the classification of Pimentel-Gómez and García (2002) was used, authors who classified the variability of an attribute according to the magnitude of its coefficient of variation, being low for values below 10\%, average between $10 \%$ and $20 \%$, high between $20 \%$ and $30 \%$ and very high if it is greater than $30 \%$.

Subsequently, adjustments for theoretical semivariogram models were made, based on the theory of regionalized variables, which provides different methods of analysis of spatial variation, one of which is semivariogram (Vieira, 2000). This analysis assumes that the measure of a property of two samples separated by a distance, is similar if the distance is small, reflecting a major difference when the distance increases. The semivariance is estimated by: 


$$
\gamma(h)=\frac{1}{2 N(h)} \sum_{i=1}^{N(h)}[Z(x i)-Z(x i+h)]^{2}
$$

where $Z(x i)$ is the sample value at each point $x i$, in which data are available both in $x i$ and in $x i+h ; N(h)$ is the number of data pairs separated by a distance $h$.

The representation of the values obtained in each region versus $\gamma(h)$ graphically is the experimental semivariogram, which adjusts with the theoretical model to estimate the coefficients of the nugget effect $\left(\mathrm{C}_{0}\right)$, plateau $\left(\mathrm{C}_{0}+\mathrm{C}_{1}\right)$ and range or scope (a). The nugget effect indicates the discontinuity between samples or the spatial variability that is not detected during the sampling process (Vieira, 2000). The plateau is the value of the semivariance where the model is stable and has a constant value. The range is the maximum distance at which values of one variable are spatially dependent. The results were fitted to spherical, exponential and Gaussian models, which are common in the study of spatial variability of soil properties. The spherical model is defined by,

$$
\gamma(h)=\left\{\begin{array}{cc}
C_{0}+C_{1}\left(\frac{3}{2}\left(\frac{h}{a}\right)-\frac{1}{2}\left(\frac{h}{a}\right)^{3}\right) & 0<h<a \\
C_{0}+C_{1} & h>a
\end{array}\right.
$$

The exponential model is defined by,

$$
\gamma(h)=C_{0}+C_{1}\left(1-\exp \left(\frac{-3 h}{a}\right)\right) \quad 0<h<d
$$

where $d$ is the maximum distance at which the semivariogram is defined. The Gaussian model is defined by:

$$
\gamma(h)=C_{0}+C_{1}\left(1-\exp \left(\frac{-h^{2}}{a^{2}}\right)\right)
$$

Once the best fit model for each property was determined, contour maps were created using ordinary kriging, which allows for the prediction of a property in the non-sampled areas. Degree of spatial dependence (DSP) was confirmed by the relationship between the nugget effect and the plateau $\left(\mathrm{C}_{0} / \mathrm{C}_{0}+\mathrm{C}_{1}\right)$. The DSP is considered strong above $75 \%$, moderate DSP is between $25 \%$ and $75 \%$ and weak is less than 25\% (Cambardella, 1994).

\section{RESULTS AND DISCUSSION}

\section{Descriptive statistical analysis}

The results obtained in the descriptive analysis showed that most of the attributes are close to normal distribution (Table 1), as indicated by similar values of mean and median, in addition to the close to zero values of skewness and kurtosis, verified by the Kolmogorov-Smirnov normality test. Normality for these attributes is reported by several authors in different soil types (Ramírez-López et al., 2008, Rodriguez-Vasquez et al., 2008).

Sand and silt content and hydraulic conductivity attributes did not follow a normal distribution, as seen in the significant result from the test for normality. In the case of sand content and hydraulic conductivity (Ks), it was observed that the values of the mean and median are distant, showing very high coefficients of variation (CV), also seen in the significant results of the Kolmogorov-Smirnov test. Silt content also varied from normal distribution despite the fact that the values of the mean and median for this attribute are similar, verified with the values of skewness and kurtosis that are distant from zero. According to Cressie (1993), more important than normality is the verification that normal distribution does 
Table 1. Descriptive analysis of soil properties.

\begin{tabular}{|c|c|c|c|c|c|c|c|c|}
\hline Property & Mean & Median & $\mathrm{CV}, \%$ & Minimum & Maximum & Skewness & Kurtosis & K-S \\
\hline $\mathrm{Da}, \mathrm{Mg} \mathrm{m}^{-3}$ & 1.40 & 1.39 & 9.52 & 1.09 & 1.67 & -0.13 & -0.46 & ns \\
\hline Dr, $\mathrm{Mg} \mathrm{m}^{-3}$ & 2.53 & 2.50 & 6.20 & 2.22 & 2.85 & 0.16 & 0.01 & ns \\
\hline Pt, \% & 44.18 & 43.30 & 13.62 & 31.49 & 59.13 & 0.44 & -0.06 & ns \\
\hline Sand, \% & 27.86 & 23.00 & 62.09 & 9.00 & 71.00 & 0.90 & -0.14 & $*$ \\
\hline Clay, \% & 36.66 & 37.00 & 38.43 & 7.00 & 59.00 & -0.36 & -0.78 & ns \\
\hline Silt, \% & 34.46 & 34.50 & 19.15 & 12.00 & 48.00 & -1.00 & 2.24 & $*$ \\
\hline HG, \% & 19.81 & 20.11 & 35.52 & 1.29 & 35.18 & -0.31 & -0.11 & ns \\
\hline $\mathrm{HV}, \%$ & 27.73 & 28.00 & 34.85 & 2.00 & 46.00 & -0.36 & -0.01 & ns \\
\hline $\mathrm{Vi}, \mathrm{cm} \mathrm{h}^{-1}$ & 1.55 & 1.48 & 73.47 & 0.12 & 4.39 & 0.66 & -0.17 & ns \\
\hline $\mathrm{Ks}, \mathrm{m} \mathrm{dia}{ }^{-1}$ & 0.48 & 0.38 & 73.50 & 0.04 & 1.36 & 0.74 & -0.33 & * \\
\hline
\end{tabular}

CV: coefficient of variation; ${ }^{(*)}$ significant to $5 \%$ by Kolmogorov-Smirnov test (K-S); Da: bulk density; Dr: particle density; Pt: total porosity; HG: gravimetric humid; HV: volumetric humid; Vi: infiltration rate; Ks: hydraulic conductivity.

not have very long tails to avoid compromising the results, especially when applied to kriging, where estimates are based on average values (Warrick and Nielsen, 1980). Another important fact is the occurrence of a proportional effect between the mean and variance data along a surface to estimate well-defined plateaus in the semivariogram models.

The behavior of the $\mathrm{CV}$ reflects the variability of the attributes studied. According to Pimentel-Gómez and García (2002), the soil attributes that showed low variability were bulk density (9.52\%) and particle density (6.20\%) (Table 1), the former because it is a mineral soil with particles of similar weight in the entire study area but with high levels of compaction, and the latter because there are no marked changes in the clay content. Average change was presented in total porosity $(\mathrm{Pt})$ which was $13.62 \%$ and silt content (19.15\%). The other attributes showed high variability, highlighting the high values of $\mathrm{CV}$ of sand (62.09\%), infiltration rate (Vi) (73.47\%) and Ks (73.50), a property that is strongly related to different textural changes in the composition of the soil (Moreno et al., 2001). The high variability of $\mathrm{Ks}$ and $\mathrm{Vi}$ can also be explained by the different uses and management of the area, leading to a decrease and disruption of the pores (Dörner et al., 2009) as well as the presence of expansive clays such as vermiculite, which induces the presence of cracks up to $1 \mathrm{~cm}$ (Khresat and Taimeh, 1998), increasing the values of water movement in soil. 


\section{Geostatistical Analysis}

All attributes adjusted to the theoretical semivariogram models, predominantly the spherical model, although Da fitted an exponential model and silt a Gaussian model (Table 2). The adjustment of different physical attributes is also reported by several authors (Duffera et al., 2007; Ramírez-López et al., 2008: Rodriguez-Vasquez et al., 2008). HG was the attribute that had the lowest coefficient of determination $\left(\mathrm{R}^{2}\right)$, showing a smaller representation of the fitted model. The other parameters showed a higher $\mathrm{R}^{2}$ of 0.70 , indicating an adequate reliability of the model. This result, together with values close to one (1) of the coefficient of cross validation, ensures a good representation of the values found, the theoretical values were estimated, which were then represented in contour maps by kriging (Faraco et al., 2008).

Table 2. Parameters of the theoretical semivariograms of soil properties.

\begin{tabular}{lccccccc}
\hline Property & Model & $\mathbf{C}_{\mathbf{0}}$ & $\mathbf{C}_{\mathbf{0}}+\mathbf{C}_{\mathbf{1}}$ & Range (m) & $\mathbf{C}_{\mathbf{1}} /\left(\mathbf{C}_{\mathbf{0}}+\mathbf{C}_{\mathbf{1}}\right)$ & $\mathbf{R}^{2}$ & $\mathbf{C V C}$ \\
\hline Da & Exponential & $3.4 \mathrm{E}^{-3}$ & 0.02 & 172.20 & 0.81 & 0.93 & 0.93 \\
$\mathrm{Dr}$ & Spherical & $8.5 \mathrm{E}^{-3}$ & 0.02 & 115.00 & 0.64 & 0.70 & 0.95 \\
$\mathrm{Pt}$ & Spherical & 1.96 & 32.84 & 102.20 & 0.94 & 0.77 & 0.68 \\
Sand & Spherical & 0.10 & 239.00 & 96.70 & 1.00 & 0.87 & 0.80 \\
Clay & Spherical & 43.70 & 169.70 & 128.60 & 0.74 & 0.85 & 0.84 \\
Silt & Gaussian & 0.10 & 68.94 & 84.87 & 1.00 & 0.83 & 0.80 \\
HG & Spherical & 0.10 & 48.36 & 103.10 & 1.00 & 0.84 & 0.79 \\
HV & Spherical & 3.90 & 98.40 & 117.00 & 0.96 & 0.94 & 0.81 \\
Vi & Spherical & 0.53 & 3.60 & 218.60 & 0.85 & 0.86 & 0.87 \\
Ks & Spherical & $4.3 \mathrm{E}-3$ & 0.09 & 150.50 & 0.95 & 0.61 & 0.94 \\
\hline
\end{tabular}

$\mathrm{C}_{0}$ : Nugget; $\mathrm{C}_{0}+\mathrm{C}_{1}$ : Sill; $\mathrm{C}_{1} /\left(\mathrm{C}_{0}+\mathrm{C}_{1}\right)$ : degree of spatial dependence; $\mathrm{R}^{2}$ : coefficient of determination of semivariogram model; CVC: coefficient of cross validation; Da: bulk density; Dr: particle density; Pt: total porosity; HG: gravimetric humid; HV: volumetric humid; Vi: infiltration rate; Ks: hydraulic conductivity.

The contents of silt and sand were attributes that had the lowest ranks, below $100 \mathrm{~m}$. Moreover, the attribute that had the greatest scope was $\mathrm{Vi}$, with a value of $218.60 \mathrm{~m}$. In general, most attributes presented ranges close to $100 \mathrm{~m}$, confirming that the distance chosen for the initial sampling between points (45 m) was appropriate as it allowed the identification of the spatial dependence for all attributes, in addition to presenting ranges less than the maximum sampling 
distance, which was approximately $500 \mathrm{~m}$ for this study, complying with the precepts of the regionalized variable theory (Vieira, 2000).

All properties had a definite plateau which suggests the presence of an unexplained microvariability in the sample due to the heterogeneity of the soil sampling sites and the fact that the properties did not have changes in their general characteristics at short distances (Arrouays et al., 2000). However, it was observed that most attributes presented a strong GDE, with values greater than 0.80, except for Dr and clay content, attributes with a moderate DSM, with values of 0.64 and 0.74 , respectively.

\section{Analysis of the spatial distribution}

Contour maps can establish relationships between the studied properties, showing some similarity between them. For example, areas with higher clay content (Figure 1E), correspond to areas with high values of Da and Dr (Figures 1A and 1B), moderate and low values of Pt (Figure $1 \mathrm{C}$ ), higher moisture content (Figures 2A and $2 \mathrm{~B}$ ) and the lowest values of $\mathrm{Vi}$ and $\mathrm{K}$ (Figures 2C and 2D). In all cases, a marked dependence was presented in the physical characteristics of the soils in the central part following a curve to the northwest part of the study zone (Figures 1 and 2). The study area has a tropical climate with high rates of precipitation followed by drought periods that generate large cracks in the soil that produce a lessivage or leaching from clay particles being carried downward and upward, generated by slickensides surfaces present in vertisols, attributed to the characteristics of vermiculite-type clay (Nordt et al., 2004). The presence of these clay minerals increases the hydraulic conductivity (Kapur et al., 1997). The spatial distribution is influenced by the geomorphology of the study area, since this zone, before being used in agricultural production, was an area with swamps and wetlands.

Bulk density is the property that presented the lowest heterogeneity, followed by soil moisture content. However, it is notable that in the southeastern part, despite being a clay soil, it has values of bulk density close to 1.6 $\mathrm{Mg} \mathrm{m}^{-3}$, which may occur with this soil due to the use of these lands for stockbreeding, possibly generating compaction problems, as well as the influence of chemical properties that affect this property such as the high exchangeable $\mathrm{Na}^{+}$percentage $(10 \%$ and $19 \%$ ) found in the study area, because it acts as an ion that disperses the soil particles. It is also responsible for separating organic matter particles of sand, silt and clay, causing poor structure in the soil (Sposito, 1989) and a decrease in the pore space (Montenegro and Malagon, 1990) that inhibits water movement into and through the soil (Bohn et al., 2001). Something similar occurs with the speed of infiltration (Figure 2C), which has moderately slow and slow values in this zone because of the presence of high levels of sodium.

Once the characteristics were described, three Agronomic Management Units (AMU's) were defined, which were determined by the similar values of the evaluated properties. The CV for the standardization of the classification of the three units was taken as reference (Table 3).

AMU 1 has an area of 3.55 ha (Figure 3), with soils with higher sand content, which present textures from sandy to sandy loam, a Da between 1.53 and 1.67 $\mathrm{Mg} \mathrm{m}^{-3}$, where plants looked healthy, tall and vigorous, with good root depth that varied between 0.45 and $0.65 \mathrm{~m}$. The kudzu planted in this AMU also has large leaves. 
Identification of agronomic management units, Cucunubá et al.
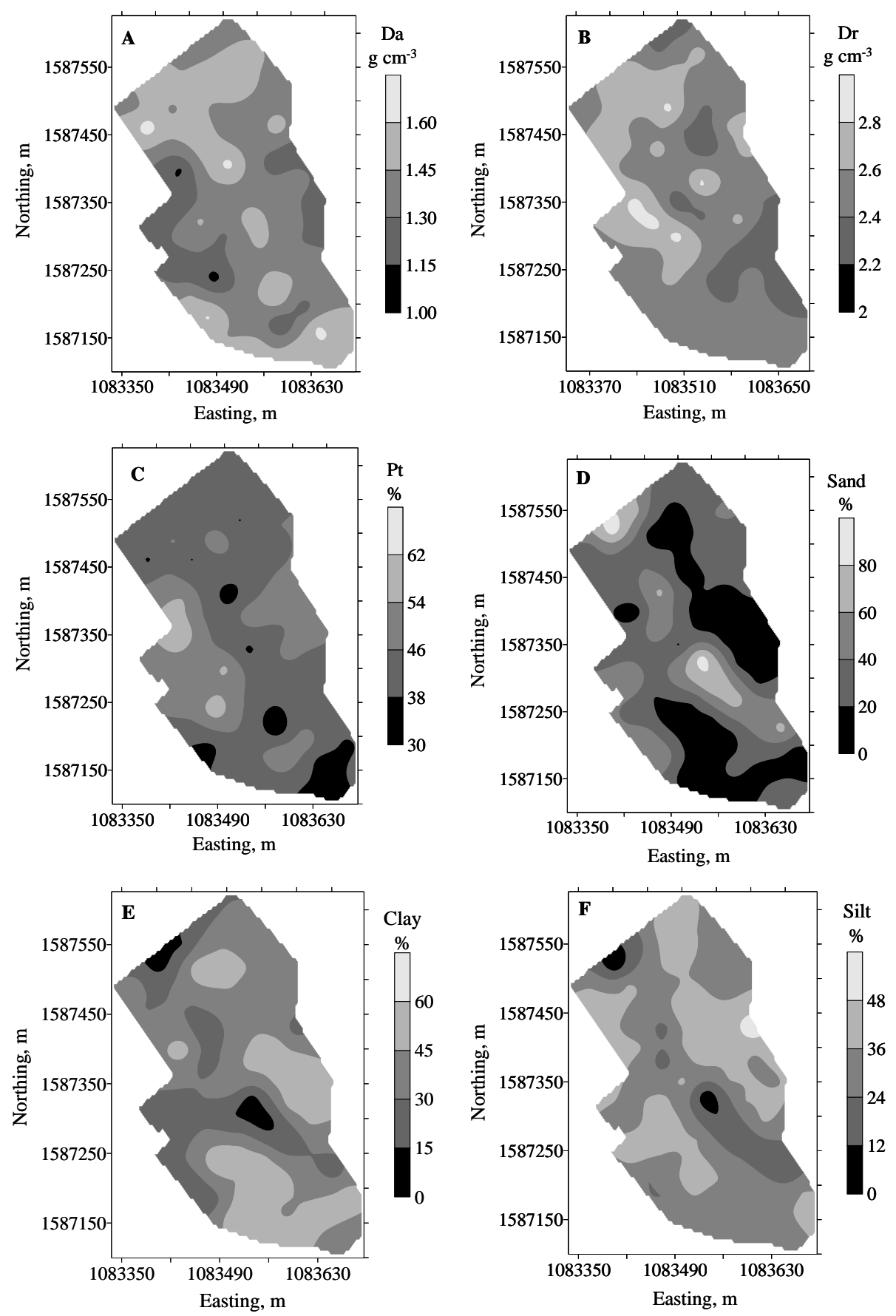

Figure 1. Contour maps obtained by kriging for bulk density (A), particle density (B), total porosity (C), sand (D), clay (E) and silt (F). 

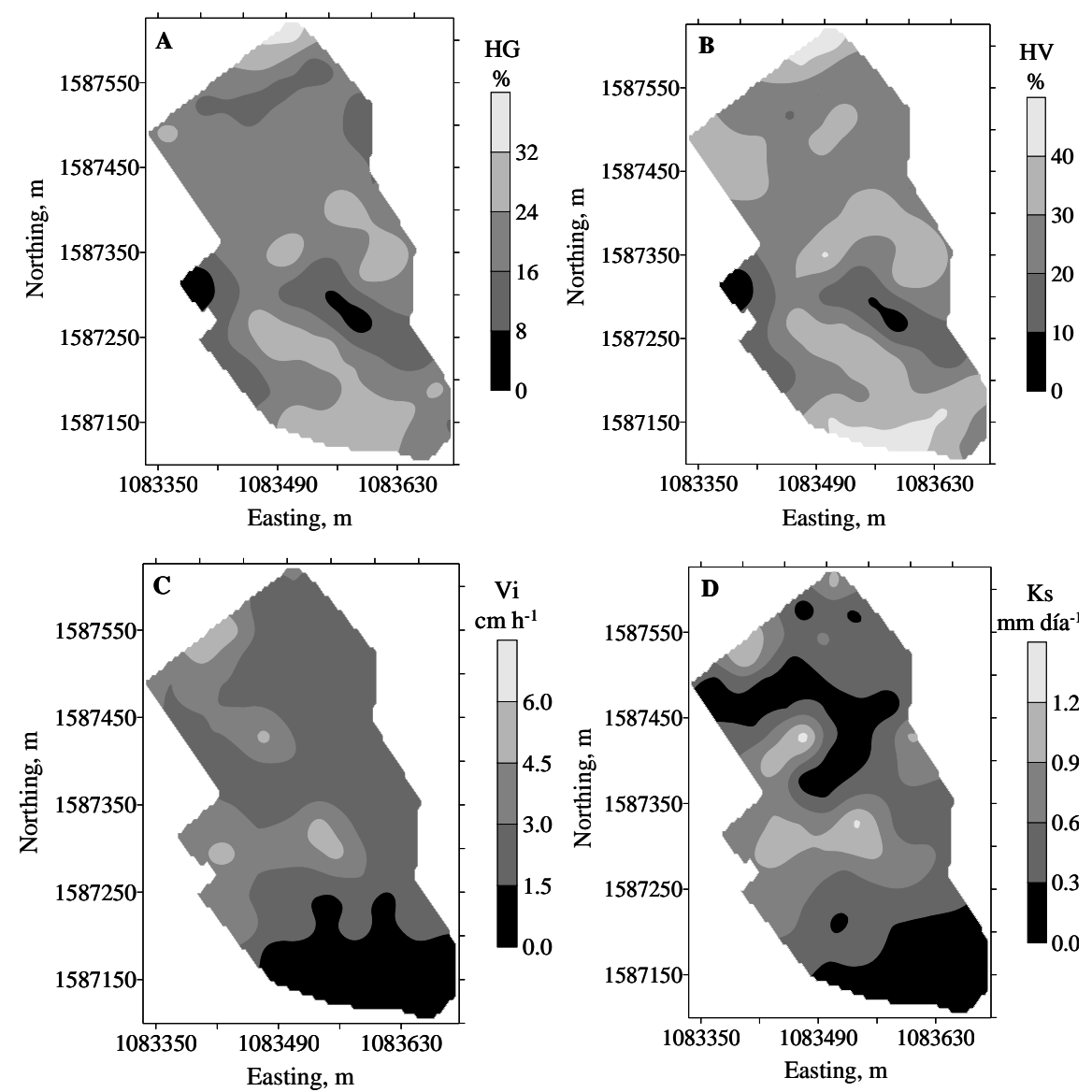

Figure 2. Contour maps obtained by kriging for gravimetric moisture (A), volumetric moisture (B) infiltration rate (C) and hydraulic conductivity (D).

AMU 2 has an area of 5.11 ha, and shows the highest contents of clay, with a texture of clay to sandy clay loam, a Pt greater than $45 \%$ and a moderate to moderately slow Vi (Montenegro and Malagon, 1990). It presents large plants, with a dark green color more intense than AMU 1, the roots reach a depth of 35 to $40 \mathrm{~cm}$. In this AMU, fruit production is higher than in AMU 1.

The third AMU has an area of 2.38 ha. This zone is similar to AMU 2, since there are no variations in texture, but there are variations in other physical characteristics such as $\mathrm{Da}$, with values close to $1.62 \mathrm{Mg} \mathrm{m}^{-3}$, Vi between slow and very slow, caused by the presence of salts, as observed in the field. This AMU has small plants, low foliar area and poor root systems that do not reach $0.20 \mathrm{~m}$, and at the time of this study had not begun fruit production.

The most important change is shown by the infiltration rate, which has a CV of $73.47 \%$ for all samples, a variation that decreased from $57.40 \%$ to $44.85 \%$, 
Identification of agronomic management units, Cucunubá et al.

Table 3. Coefficient of variation for each Agronomic Management Unit (AMU)

\begin{tabular}{lcccc}
\hline \multirow{2}{*}{ Property } & \multicolumn{4}{c}{ Coefficient of variation, \% } \\
\cline { 2 - 5 } & Initial & AMU 1 & AMU 2 & AMU 3 \\
\hline Da & 9.52 & 7.83 & 9.86 & 9.74 \\
Dr & 6.20 & 6.39 & 6.56 & 3.67 \\
Pt & 13.62 & 13.74 & 12.80 & 14.76 \\
Sand & 62.09 & 26.24 & 52.20 & 77.44 \\
Clay & 38.43 & 40.58 & 25.67 & 25.34 \\
Silt & 19.15 & 62.68 & 18.06 & 25.82 \\
HG & 35.52 & 55.70 & 26.49 & 27.49 \\
HV & 34.85 & 58.70 & 23.92 & 30.36 \\
Vi & 73.47 & 44.85 & 57.40 & 59.23 \\
Ks & 73.50 & 26.02 & 61.83 & 96.95 \\
\hline
\end{tabular}

Da: bulk density; Dr: particle density; Pt: total porosity; HG: gravimetric humid; HV: volumetric humid; Vi: infiltration rate; Ks: hydraulic conductivity.

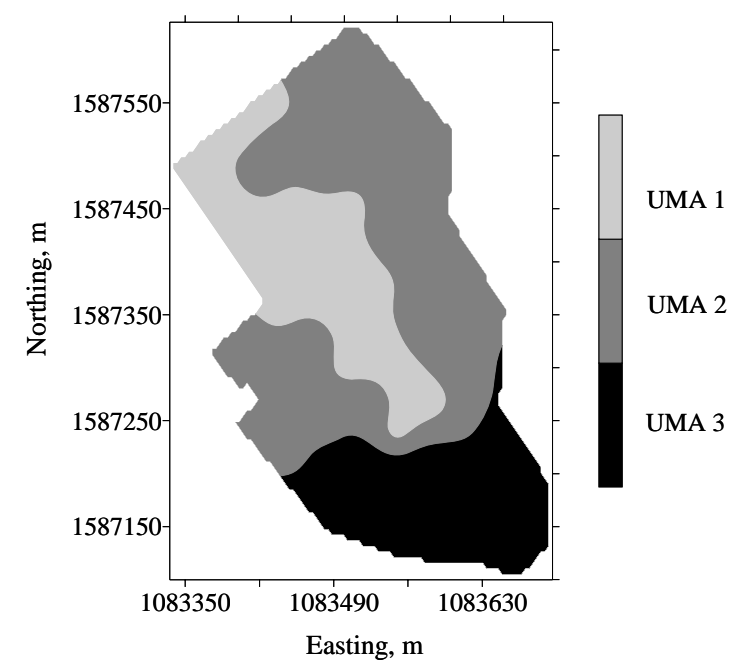

Figure 3. Agronomic management units (AMU) for the study area. 
allowing the definition of the AMU's. It is important to note that the $\mathrm{CV}$ of the sand content for AMU 3 contrasts with the $\mathrm{CV}$ of the infiltration rate, due to the compaction caused by sodium in this unit. The CV in all the other properties was higher in AMU 1 and 2 caused by the great variability of soils in these areas. This needed the classification of the areas with similar characteristics and behaviors, which gave rise to three AMU's, having marked differences between them in the infiltration rate.

Significant clay content was observed in the study area due to the mineralogical characteristics and the pedogenetic processes of these soils, given the ease with which the clays migrate from one place to another and the phenomena of contraction and expansion this soil presents.

High bulk density, low porosity and slow infiltration rate determined AMU 3, due to the fact that soil compaction is a barrier to root development of the palm, plus high sodium contents, which limit the conditions for crop growth and therefore prompt the corrective application of gypsum amendments and additions of organic matter prior to the planting of the crop, in order to improve the physical and chemical properties.

In general, AMU 2 was determined by higher clay content and low sand content, showing moderate to low infiltration rates. The silt content is in the middle range, which is similar in all the AMUs.

\section{CONCLUSIONS}

All attributes presented variability, low for the bulk density and particle density and high for sand content, infiltration rate and hydraulic conductivity. This variability adjusted to theoretical models for the properties analyzed. The properties presented a well defined spatial dependence, and adjusted predominantly to a spherical model with high degrees of spatial dependence, except for the particle density.

The use of kriging for the contour maps allowed for the identification of management zones and the relationship between different soil physical properties, which facilitated their subsequent classification to determine Agronomic Management Units. However, at the time of applying this methodology to obtain AMU's, it is important to locate and describe any details that provide a clear picture of the status of the plant, in terms of age, variety, health, physiological state or abnormal behavior for the purpose of modifying crop management.

For future studies, the effect of all the physical properties of the soil and the relationship with organic matter should be considered. This methodology can also be applied in studies of other production systems, considering the biological characteristics of plants for proper implementation of specific site management, leading to the optimization of crop productivity.

\section{ACKNOWLEDGMENTS}

To the Soil and Water program of CENIPALMA, for financial support. To Aceites S.A., for logistical support.

\section{REFERENCES}

Arrouays, D., Martín, S., Lepretre, A., Bourennane, H. 2000. Short-Range spatial variability of metal content in soil on a one hectare agricultural plot. Commun. Soil Sci. Plant Anal. 31, 387-400. 
Bohn, H.L., McNeal, B.L., O'Connor, G.A. 2001. Soil chemistry. New York: John Wiley and Sons, Inc., 307 p.

Burrough, P., MacDonell, R. 1998. Principles of geographical information systems. New York: Oxford University Press, 352 p.

Camacho-Tamayo, J.H., Luengas, C.A., Leiva, F.R. 2008. Effect of agricultural intervention on the spatial variability of some soils chemical properties in the eastern plains of Colombia. Chilean J. Agric. Res. 68, 42-55.

Cambardella, C.A., Moorman, T.B., Novak, J.M., Parkin, T.B., Karlen, D.L., Turco, R.F., Konopka, A.E. 1994. Field-scale variability of soil properties in Central Iowa Soils. Soil Sci. Soc. Am. J. 58, 1501-1511.

Cressie, N. 1993. Statistics for spatial data Revised Edition. John Wiley \& Sons, New York, USA. 928 p.

Dale, M., Dixon, P., Fortin, M., Legendre, P., Myers, D. Rosemberg, M. 2002. Conceptual and mathematical relationships among methods for spatial analysis. Ecography 25, 558-77.

Diggle, P.J., Ribeiro, J.R. 2000. Model Based Geostatistics. 1ed. São Paulo: Associação Brasileira de Estatística. 129 p.

Dorner, J., Dec, D., Peng, X., Horn, R. 2009. Efecto del cambio de uso en la estabilidad de la estructura y la función de los poros de un Andisol (Typic Hapludand) del sur de Chile. J. Soil Sci. Plant Nutr. 9, 190-209.

Duffera, M., White, J.G., Weisz, R. 2007. Spatial variability of Southeastern U. S. Coastal Plain soil physicial properties: Implications for site-specific management. Geoderma 137, 327339.

Duran, N., Ortíz, R.A. 1995. Efecto de algunas propiedades físicas del suelo y la precipitación sobre la producción de la palma aceitera (Elaeis guineensis) en Centroamérica. Agromeso 6, 7-14.

Faraco, M.A., Uribe-Opazo, M.A., Silva, E.A.A., Johann, J.A., Borssoi, J.A. 2008 Seleção de modelos de variabilidade espacial para elaboração de mapas temáticos de atributos físicos do solo e produtividade da soja. Rev. Bras. Ciênc. Solo 32, 463-476.

Fietz, C.R., Folegatti, M.V., Vieira, S.R., Frizzone, J.A. 1999. Efeito da variabilidade do armazenamento de agua no solo na qualidade da irrigação por aspersão. R. Bras. Eng. Agríc. Amb. 3, 150-153.

Garzón, E. 2008. Manejo Integrado de Suelos para la zona norte palmera. Curso taller. Aracataca, Magdalena.

Godwin, R.J., Miller, P.C.H. 2003. A review of the technologies for mapping within-field variability. Biosyst. Eng. 84, 393-407.

Kapur,S., Karaman, C., Akca, E., Aydin, M., Dinc, U., FitzPatrick, E.A., Pagliai, M. Kalmar, D., Mermut, A.R. 1997. Similarities and differences of the spheroidal microstructure in Vertisols from Turkey and Israel. Catena 28, 297-311.

Khresat, S.A., Taimeh, A.Y. 1998. Properties and characterization of vertisols developed on limestone in a semi-arid environment. J Arid Environ. 40, 235-244.

Molin, J.P., Leiva, F.R., Camacho-Tamayo, J.H. 2008. Tecnología de la agricultura de precisión en el contexto de la sostenibilidad. En: Leiva, F.R. (Ed.). Agricultura de precisión en cultivos transitorios. Bogotá, Universidad Nacional de Colombia. pp. 13-41.

Moreno, F., Cabrera, F., Fernández, J.E., Girón, I.F. 2001. Propiedades hidráulicas y concentración de metales pesados en los suelos y en las aguas de drenaje de dos zonas afectadas por el vertido. Boletín Geológico y Minero 112, 178-184.

Montenegro, H., Malagón, D. 1990 Propiedades físicas de los suelos. Instituto Geográfico Agustín Codazzi (IGAC). Subdirección Agrológica. Bogotá. 812 p.

Munévar, F. 1998. Problemática de los suelos cultivados con palma de aceite en Colombia. Palmas (Colombia) 19 ( $\mathrm{N}^{\circ}$ Especial), pp. 218 228.

Nordt, L., Wilding, L., Lynn, W., Crawford, C. 2004. Vertisols genesis in a humid climate of the coastal plain of Texas, U.S.A. Geoderma 122, 83-102.

Pimentel-Gómez, F., García, C.H. 2002. Estatística aplicada a experimentos agronômicos e florestais: exposição com exemplos e orientações para uso de aplicativos. Piracicaba, FEALQ. 309 p.

Ramírez-López, L., Reina-Sánchez, A., Camacho-Tamayo, J.H. 2008. Variabilidad 
espacial de atributos físicos de un Typic Haplustox de los Llanos Orientales de Colombia. Eng. Agríc. 28, 55-63

Rodríguez-Vásquez, A.F., Aristizabal-Castillo, A.M., Camacho-Tamayo, J.H. 2008. Variabilidad espacial de los modelos de infiltración de Philip y Kostiakov en un suelo ándico Eng. Agríc. 28, 64-75.

Rubiano, Y. 2005. Conceptos básicos para utilizar los levantamientos de suelos en el manejo agronómico de la palma de aceite. Proyecto Caracterización de suelos y determinación de Unidades de Manejo Agronómico en Plantaciones de la Zona Central Palmera. Bogotá, Colombia.

Sposito G. 1989. The chemistry of soils. Oxford University Press, New York, 277 p.
United States Department of Agricultura USDA. 2006. Claves para la Taxonomía de Suelos. Soil Survey Staff. Departamento de Agricultura de los Estados Unidos. Servicio de Conservación de Recursos Naturales. Decima Edición. 339 p.

Vieira, S.R. 2000. Geoestatística em estudos de variabilidade espacial do solo. In: Novais, P.F., Alvarez,V.H., Schaefer,C.E.G.R. (eds.). Tópicos em ciência do solo. Viçosa: Sociedade Brasileira de Ciência do Solo 1, 1-54.

Warrick, A.W., Nielsen, D.R. 1980. Spatial variability of soil physical properties in the field. En: Hillel, D. (ed). Applications of soil physics. New York: Academic Press, 1980. pp. 319-344. 